\title{
KONSTRUKSI MAKNA MINORITAS DALAM INTERAKSI SOSIAL MAHASISWA ETNIS TIONGHOA DI UNIVERSITAS BUDI LUHUR DAN UNIVERSITAS BINA NUSANTARA
}

\author{
Ni Gusti Ayu Ketut Kurniasari \\ Program Studi Ilmu Komunikasi, Fakultas Ilmu Komunikasi, Universitas Budi Luhur \\ jegegyuke@gmail.com
}

\begin{abstract}
In its development, the existence of ethnic Indonesians Chinese descent is inseparable from the development of governmental system in the Country. Since the New Order era, the ethnic members have been playing pivotal role in economic realm. However a significant development occurred during the era of Abdurrahman Wahid administration that allowed access for Indonesians Chinese to attend school or study in public universities. Since then, educational institutions in Indonesia have been accommodated multiculturalism by recognising the existence of various ethnics in Indonesia, although the term of minority for certain ethnics still become problem and inherent identity. Therefore, this research raised the title; Construction meaning of minority in social interaction of Chinese Indonesian students at Universitas Budi Luhur and Universitas Bina Nusantara. The problem formulation in this research is: How purport identity ethnic minority Chinese students in social interaction at the Universitas Budi Luhur and Universitas Bina Nusantara? How does social interaction performed by students of Chinese ethnicity at Universitas Budi Luhur and Universitas Bina Nusantara? This study also uses the theory of identity and theory phenomenology by George Herbert Mead. But as a result of this research was the meaning/significance of Indonesian Chinese minority identity is strongly linked with social interaction occurred. The awareness to boldly preserve and display Ethnic's culture and traditions begins in families. This serves as guidelines to determine how to behave and interact within the community of Indonesians Chinese and within university life. Social interaction within the ethnic group is varied depending on religious beliefs, languages, and cultural stereotypes have become distinguishing factors of social interaction process.
\end{abstract}

Keywords: Meaning, minority, chinese, social interaction.

\begin{abstract}
ABSTRAK
Pada perkembangannya, eksistensi etnis tionghoa di Indonesia, tidak bisa dilepaskan dari perkembangan sistem pemerintahan di Indonesia. Sejak era Orde Baru inilah, etnis Tinghoa mulai diperhitungkan secara ekonomi. Namun perkembangan yang sangat signifikan terjadi pada era pemerintahan Gus Dur, yang membuka akses untuk etnis Tionghoa dapat bersekolah atau menempuh pendidikan dimana saja. Hingga dapat dikatakan bahwa, institusi pendidikan di Indonesia telah mengakomodasi multikultur dengan mengakui keberadaan dari berbagai etnik yang ada di Indonesia, walaupun istilah minoritas bagi etnis tertentu masih menjadi masalah dan menjadi identitas yang melekat. Dengan demikian, penelitian ini mengangkat judul; Konstruksi Makna Minoritas dalam Interaksi Sosial Mahasiswa Etnis Tionghoa di Universitas Budi Luhur dan Universitas Bina Nusantara. Se-
\end{abstract}


bagai rumusan masalah dalam penelitian ini adalah: Bagaimana pemaknaan identitas minoritas mahasiswa Etnis Tinghoa dalam interaksi sosial di Universitas Budi Luhur dan Universitas Bina Nusantara? Bagaimana interaksi sosial yang dilakukan oleh mahasiswa etnis Tionghoa di Universitas Budi Luhur dan Universitas Bina Nusantara? Penelitian ini juga menggunakan teori Identitas serta teori Fenomenologi George Herbert Mead. Adapun sebagai hasil dari penelitian ini adalah Pemaknaan identitas minoritas etnis Tionghoa memiliki keterkaitan yang sangat erat dengan proses interaksi sosial yang dilakukan. Dimana kesadaran yang mereka tampilkan dalam kebanggaan menjadi seorang keturunan Tionghoa dengan terus menjaga tradisi-tradisi Tionghoa yang ditanam sangat kental dimulai dari keluarga, dan mereka yakni sebagai sebuah pondasi dalam menentukan sikap dan perilaku pada saat mereka membangun proses interaksi baik sesama etnis Tionghoa maupun dengan masyarakat pribumi dilingkungan universitas. Terkait dengan interaksi sosial yang dilakukan oleh mahasiswa etnis Tionghoa di lingkungan pendidikan pun menjadi sangat variatif dimana agama, bahasa hingga stereotype budaya yang mereka miliki menjadi varian-varian atau warna tersendiri dalam proses interaksi sosial yang dilakukan.

\section{Kata-kata Kunci: Makna, minoritas, tionghoa, interaksi sosial.}

\section{PENDAHULUAN}

Perkembangan etnis Tionghoa yang ada di Indonesia tentu menjadi sangat menarik, karena eksistensi etnis Tionghoa pun tidak luput dari perkembangan sejarah hingga pemerintahan Indonesia. Setiap fase pemerintahan pun akan memiliki dampak yang sangat signifikan terhadap etnis Tionghoa yang ada di Indonesia. Dalam sejarahnya, kedatangan leluhur suku Tionghoa (yang berasal dari negera China) untuk bermigrasi ke Indonesia terjadi pada ratusan bahkan ribuan tahun yang lalu (utamanya pada abad ke 16-19). Pada umumnya, etnis Tionghoa datang ke Indonesia dengan tujuan awal untuk berdagang (dalam perniagaan). Ramainya interaksi perdagangan di daerah pesisir tenggara China, menyebabkan banyak orang yang tinggal di daerah pesisir China ingin ikut berlayar untuk berdagang. Tujuan utama dari etnis Tionghoa saat itu adalah Asia Tenggara, karena kegiatan pelayaran sangat tergantung pada angin musim. Setiap tahunnya para pedagang akan bermukim di wilayah-wilayah yang mereka singgahi (http://www.tionghoa.info/sukutionghoa-di-indonesia/)

Berdasarkan sejarah perkembangan etnis Tionghoa hingga sampai di Indonesia yang singgah dibeberapa daerah dan tidak berpusat pada satu daerah saja, dimana salah satu daerah tersebut adalah Jakarta. Khususnya untuk DKI Jakarta sendiri, dari berjuta-juta penduduk Kota Jakarta terdapat pembagian suku bangsa yang beraneka ragam. Semua suku bangsa yang ada secara umum dapat hidup berdampingan dengan rukun dan damai. Dari data yang ada di bawah ini 
dapat dilihat bahwa mayoritas warga Jakarta adalah orang-orang yang berasal dari daerah Jawa. Selain etnis Jawa, etnis Betawi dan etnis Sunda juga merupakan etnis yang cukup mayoritas di DKI Jakarta yang jumlahnya lebih dari 10\%. Berdasarkan sumber dari beberapa data, bahwa prosentase suku yang ada di Jakarta adalah sebagai beritu: Suku Jawa (35,16\%), Suku Betawi (27,65\%), Suku Sunda $(15,27 \%)$, Suku Tionghoa (5,53\%), Suku Batak (3,61\%), Suku Minang (3,18\%), Suku Melayu (1,62\%), Suku Lain-lain (7,98\%). Dari olah data yang diramu dari berbagai sumber tersebut dapat dilihat bahwa, etnis Tionghoa memiliki jumlah yang cukup banyak di Jakarta yaitu sebanyak 5,53\%. Tentu saja, itu menjadi jumlah yang cukup diperhitungkan untuk diwilayah DKI Jakarta. (www. demografi.bps.go.id)

Jika dilihat pada perkembangan eksistensi etnis tionghoa di Indonesia, maka tidak bisa dilepaskan dari perkembangan sistem pemerintahan di Indonesia. Dimana setiap era pemerintahan memiliki dampak yang berbeda terhadap keberadaan etnis Tionghoa di Indonesia. Pada era Orde Baru, etnis Tionghoa hanya mengalami keterbatasan akses pada wilayah sosial dan politik. Namun pada sektor perekonomian, etnis Tionghoa mendapatkan peluang yang sama dengan masyarakat pribumi. Bahkan sejak era Orde Baru inilah, etnis Tinghoa mulai diperhitungkan secara ekonomi.

Berbeda dengan era Orde Baru, maka berbeda juga di era reformasi. Walau pada saat era reformasi terjadi, etnis Tionghoa mengalami pergolakan yang sangat besar dimana pada kondisi tertentu, etnis Tionghoa menjadi luapan kemarahan dari masyarakat pribumi. Pada masa Pemerintahan Habibie beragam etnis sudah mulai melebur, dimana etnis Tionghoa pun sudah mengalami pembaharuan dengan sistem sosial yang dilakukannya. Dan perubahan yang sangat signifikan terjadi pada era pemerintahan Abdurahman Wahid (Gus Dur) yang secara lantang dan berani untuk mengakui etnis Tionghoa sebagai bagian dari etnis yang ada di Indonesia. Bahkan etnis Tionghoa memiliki kesempatan yang sama dengan masyarakat pribudi disegala aspek kehidupan. Pada era Gus dur ini juga, hari raya tahun baru Cina atau Imlek menjadi libur nasional dan mengakui Konghucu sebagai agama ke enam yang ada di Indonesia. Hal tersebut tentu saja berdampak signifikan terhadap sistem pendidikan yang ada di Indonesia. Dimana pada era Gus Dur inilah yang membuka akses untuk etnis Tionghoa dapat bersekolah atau menempuh pendidikan dimana saja. Hingga dapat 
dikatakan bahwa, saat ini pendidikan di Indonesia memang telah mengakomodasi multikultur dengan mengakui keberadaan dari berbagai etnik yang ada di Indonesia, walaupun istilah minoritas bagi etnis tertentu masih menjadi masalah dan identitas yang melekat.

Terbukanya akses pendidikan yang sangat luas pada etnis Tionghoa sehingga mengakibatkan beberapa etnis Tionghoa mampu mendominasi pada institusi pendidikan tertentu dan juga tetap menjadi minoritas di beberapa institusi pendidikan di Jakarta. Salah satu institusi pendidikan yaitu Universitas Bina Nusantara yang ada di Jakarta adalah kampus yang memiliki mahasiswa dengan jumlah mayoritas. Sementara salah satu kampus yang memiliki jumlah mahasiswa etnis Tionghoa namun dalam skala minoritas adalah Universitas Budi Luhur. Berdasarkan hasil observasi awal yang dilakukan oleh peneliti, bahwa mahasiswa etnis Tionghoa tersebut tetap berinteraksi dengan etnis lainnya yang ada di kampus - kampus tersebut. Dengan demikian, penelitian ini mengangkat judul; Konstruksi Makna Minoritas dalam Interaksi Sosial Mahasiswa Etnis Tionghoa di Universitas Budi Luhur dan Universitas Bina Nusantara.

Adapun sebagai rumusan masalah dalam penelitian ini adalah:
1. Bagaimana pemaknaan identitas minoritas mahasiswa Etnis Tinghoa dalam interaksi sosial di Universitas Budi Luhur dan Universitas Bina Nusantara?

2. Bagaimana interaksi sosial yang dilakukan oleh mahasiswa etnis Tionghoa di Universitas Budi Luhur dan Universitas Bina Nusantara?

\section{KERANGKA PEMIKIRAN}

\section{Teori Identitas}

Hecht menguraikan identitas melebihi pengertian sederhana akan dimensi diri dan dimensi yang digambarkan. Kedua dimensi tersebut berinteraksi dalam rangkaian empat tingkatan atau lapisan. Tingkatan pertama adalah Personal Layer, yang terdiri dari rasa akan keberadaan diri anda dalam situasi sosial. Dalam situasi tertentu seperti ketika menghadiri gereja, bermain dengan teman, mendekati professor tentang nilai, atau bepergian bersama keluarga, anda melihat diri anda dalam kondisi-kondisi tertentu. Identitas tersebut terdiri dari berbagai perasaan serta ide tentang diri sendiri, siapa dan seperti apa diri anda sebenarnya. Tingkatan kedua adalah Enactment Layer atau pengetahuan orang lain tetang diri anda berdasarkan pada apa yang anda lakukan, apa yang anda miliki, dan 
bagaimana anda bertindak. Penampilan anda adalah simbol-simbol aspek anda serta orang lain akan mendefinisikan dan memahami anda melalui penampilan tersebut. Tingkatan yang ketiga dalam identitas anda adalah Relational atau siapa diri anda dalam kaitannya dengan individu lain. Identitas dibentuk dalam interaksi anda dengan mereka. Anda dapat melihat dengan sangat jelas identitas hubungan ketika anda merujuk diri anda secara spesifik sebagai mitra hubungan, seperti ayah, suami istri, rekan kerja. Perhatikan bahwa identitas anda menjadi terikat kepada peran tertentu yang berhadap-hadapan dengan peran lain, seperti "bos', "sahabat karib", "koki", atau "konsuler". Oleh karena itu, pada tingkat hubungan, identitas sangat tidak individualis, tetapi terikat pada hubungan itu sendiri. Tanyalah diri anda seperti apa hubungan anda dengan ibu anda, kekasih atau teman sekamar dan mulailah memvisualisasikan identitas hubungan ini. Littlejohn\&Foss $(2009 ; 131)$

Akhirnya, tingkatan keempat dalam identitas adalah tingkatan Communal, yang diikat pada kelompok atau budaya yang lebih besar. Tingkat identitas ini sangat kuat dalam banyak budaya Asia, misalnya, ketika identitas seseorang dibentuk terutama oleh komunitas yang lebih besar daripada oleh perbedaaan individu diantara manusia dalam komunikasi. Kapan pun anda memperhatikan apa yang dipikirkan dan dilaksanakan oleh komunitas anda, maka anda menyesuaikan diri pada tingkatan identitas anda tersebut. Littlejohn\&Foss $(2009 ; 132)$

\section{Teori Interaksi Simbolik George Herbert Mead}

Salah seorang tokoh yang terkenal dari pendekatan Interaksionisme simbolik (dalam Mulyana;2004;68) ini adalah George Herbert Mead, seorang Guru Besar Filsafat dari Universitas Chicago, Amerika Serikat. Pemikiran filosofis Mead pada dasarnya merupakan pandangan aliran " Pragmatis ". Perkembangan pendekatan interaksionisme simbolik ini menurut Manfort Khun, dapat dibagi dalam 2 (dua) periode. Periode pertama, merupakan periode tradisional dan menjadi awal perkembangan dasar dasar pemikiran Interaksionisme Simbolik. Tokoh - tokohnya yang dikenal antara lain Charles Cooley, John Dewey, LA Richard dan George Herbert Mead, karya Mead tentang " Mind, Self and Society " (Pemikiran, Diri, Masyarakat) merupakan bahan pegangan pemikiran yang utama. Oleh karena itu, 
periode ini disebut juga sebagai periode" mead " atau " meadian ". Periode kedua, disebut sebagai masa pengkajian atau penyelidikan, muncul beberapa tahun setelah publikasi karya Mead. Tokoh tokoh yang muncul pada masa ini antara lain Herbert Blummer (penerus aliran Chicago School) dan Manford Kuhn (The Iowa School) dan Kenneth Burke.

Mead (dalam Mulyana;2004;68), berpandangan bahwa :

Studi tentang tingkah laku manusia pada dasarnya tidak dapat dilakukan dengan cara yang sama seperti cara mempelajari benda - benda. Manusia, menurut aliran ini, adalah mahluk yang kreatif, inovatif dan bebas. Mendefinisikan setiap situasi melalui berbagai cara yang mungkin tidak dapat diduga sebelumnya. Keberadaan diri manusia (self) dan keberadaan masyarakat (society) dilihat sebagai proses, bukan struktur tetap. Apabila kembali ke pemikiran Mead, ada 3 (tiga) konsep utama yang diajukan olehnya yakni : "Mind, Self, and Society " (pemikiran, diri dan masyarakat). Ketiga konsep ini menurut Mead merupakan unsur - unsur utama yang terlibat dalam proses yang disebut " tindakan sosial ". Tindakan sosial, menurut Mead, merupakan suatu unit lengkap yang terjadi dan tidak dapat dianalisis secara sepotong potong. Bentuk dasar tindakan sosial adalah : aksi, reaksi dan hasil interaksi. Hasil interaksi adalah makna yang diperoleh komunikator atas tindakan yang dilakukannya. Dengan demikian, makna bukanlah sesuatu yang berdiri sendiri, melainkan merupakan hasil dari keterkaitan dari tiga unsur tersebut diatas.

Mead (dalam Mulyana;2004;68), lebih lanjut mengatakan :

Bahwa orang adalah aktor (pelaku) dalam masyarakat bukan reaktor, sementara "Social Act" (tindakan sosial) merupakan payungnya. Tindakan sosial ini, menurut Mead, mencakup 3 (tiga) tahapan yang saling berkaitan : (1) initial gesture (gerak isyarat awal) dari seorang individu, (2) response (tanggapan) atas gerak isyarat tersebut dari individu individu lainnya baik secara nyata maupun secara tersembunyi, dan (3) hasil tindakan (interaksi) yang dipersepsikan oleh kedua belah pihak.

Mead berpandangan bahwa masyarakat (society) merupakan himpunan dari perbuatan - perbuatan kooperatif yang berlangsung diantara para warga/anggotanya. Namun demikian, perbuatan kooperatif ini tidak hanya berkaitan dengan proses fisik biologis, tetapi juga aspek psikologis karena melibatkan proses berfikir (minding). " cooperation" atau kerjasama mengandung arti membaca atau memahami tindakan dan maksud orang lain agar dapat berbuat sesuai dengan cara yang diinginkan orang - orang lain. Pemikiran bahwa masyarakat merupakan rangkaian interaksi penggunaan simbol - 
simbol yang kooperatif, pada dasarnya menekankan pentingnya aspek berbagi arti (sharing) atas simbol - simbol yang digunakan diantara para anggota masyarakat interaksi sosial, dengan demikian dapat dikatakan sebagai hasil perpaduan antara pemahaman diri sendiri (self) dan pemahaman atau pemikiran (mind) atas orang - orang lain dalam masyarakat (society). Inilah pokok pokok pikiran mengenai" Mind, Self, and Society" sebagaimana dikemukakan oleh George Herbert Mead.

Pertukaran makna dan simbol yang dihasilkan melalui proses interaksi Simbolik yang dilakukan oleh para mahasiswa etnis Tionghoa dalam lingkungan kampus bahwa ditemukan adanya asumsi tentang kesepakatan makna yaitu suatu kesepakatan tentang penggunaan bahasa Indonesia dalam sebuah forum resmi, identitas budaya dan agama yang melekat sebagai jati diri mereka.

\section{METODE PENELITIAN}

Tradisi fenomenologi menurut Creswell;1998;51 yang menyatakan bahwa "Whereas a biography reports the life of a single individual, a phenomenological study describes the meaning of the lived experiences for several individuals about a concept or the phenomenon". Studi tentang fenomenologi dengan demikian, berupaya menjelaskan makna pengalaman hidup sejumlah orang tentang suatu konsep atau gejala, yang dalam hal ini adalah mahasiswa etnis Tionghoa termasuk di dalamnya konsep - diri atau pandangan hidup mereka sendiri.

Husserl juga mencoba memaparkan nilai pengalaman seseorang dalam metode fenomenologi yaitu "Most phenomenologists today would say that experience is subjective, not objective, and that we need to value subjectivity as an important kind of knowledge in its own sake “. Hal terpenting dalam fenomenologi adalah pada saat mengatakan pengalaman adalah subjektif bukan objektif dan kita membutuhkan nilai subjectifitas yang merupakan suatu hal yang penting untuk mendapatkan pengetahuan menuju suatu kepentingan. Husserl (dalam Walsh dan Lehnert;1972;54) menyatakan serta menekankan perilaku merupakan “ manfaat pemahaman pengalaman dari kesadaran “. Dimana Husserl juga menyatakan bahwa :

"Experiences of primordial passivity, associations, those axperiences in which the original time-consciousness, the constitution of immanent temporality takes place and other axperiences of this kind, are all incapable of it"(that is, of conferring meaning). A meaningendowing experience must rather be an "Ego-Act (attitudinal Act) 
or some modification of such an Act (secondary passivity, or perhaps a passively emerging judgment that suddenly 'occurs to me')".

Pengalaman dari sebuah kepasifan masa lalu, berhubungan dengan waktu awal kejadian, keadaan sementara yang terjadi dan pengalaman lain jenis ini tidak terlalu berpengaruh (dalam hal memberikan maknanya). Pemahaman manfaat pengalaman harus lebih dari "Tindakan ego ( Tindakan Sikap) atau beberapa perubahan dari suatu tindakan ( kepasifan sekunder, atau mungkin kepasifan pengambilan keputusan yang secara tiba - tiba terjadi "kepada saya").

Penelitian ini menggunakan teknik wawancara dan observasi sebagai data utama serta studi pustaka sebagai data pendukung. Wawancara dilakukan secara mendalam dalam lingkungan pendidikan atau lingkungan kampus tempat para informan menempuh studinya. Wawancara dilakukan secara santai disaat para informan sudah selesai melakukan kegiatan perkuliahaan. Observasi juga dilakukan di lingkungan kampus tempat para informan menempuh pendidikan mereka yaitu di Universitas Budi Luhur dan Universitas Bina Nusantara.

Penelitian ini menekankan pada dua hal yang akan dikaji yaitu berkaitan dengan pemaknaan yang dilakukan oleh mahasiswa etnis Tionghoa terkait dengan identitas minoritas dalam interaksi sosial yang mereka lakukan di lingkungan kampus khususnya, serta penekanan yang kedua yaitu berkaitan dengan pemaknaan pada proses interaksi sosial yang dilakukan oleh mahasiswa etnis Tionghoa dilingkungan pendidikan khususnya dilingkungan kampus atau universitas. Penelitian ini dilakukan di dua universitas yang berbeda di DKI Jakarta. Dengan mewawancarai 10 (sepuluh) informan yang memiliki latar belakang mahasiswa dari beberapa jurusan serta berasal dari Universitas Budi Luhur dan Universitas Bina Nusantara.

Tabel 1

Data Deskripsi Informan

\begin{tabular}{|c|c|c|}
\hline NO & Kode & Deskripsi Informan \\
\hline 1 & $\mathrm{An}$ & Mahasiswa Universitas Budi Luhur \\
\hline 2 & $\mathrm{Fr}$ & Mahasiswa Universitas Budi Luhur \\
\hline 3 & $\mathrm{Mi}$ & Mahasiswa Universitas Budi Luhur \\
\hline 4 & $\mathrm{Iw}$ & Mahasiswa Universitas Budi Luhur \\
\hline 5 & $\mathrm{Ad}$ & Mahasiswa Universitas Budi Luhur \\
\hline 6 & $\mathrm{Na}$ & Mahasiswa Universitas Bina Nusantara \\
\hline 7 & $\mathrm{Fe}$ & Mahasiswa Universitas Bina Nusantara \\
\hline 8 & $\mathrm{Be}$ & Mahasiswa Universitas Bina Nusantara \\
\hline 9 & $\mathrm{Ti}$ & \\
\hline
\end{tabular}




\begin{tabular}{|l|l|l}
\hline 10 & Di & Mahasiswa Universitas Bina Nusantara
\end{tabular}

Sumber: Hasil Olah Data Lapangan, 2017

\section{HASIL DAN PEMBAHASAN}

\section{Pemaknaan Identitas Minoritas Mahasiswa Etnis Tionghoa da- lam Interaksi Sosial di Univer- sitas Budi Luhur dan Universi- tas Bina Nusantara}

Berkaitan dengan jumlah penduduk etnis Tionghoa yang hanya mencapai $5,53 \%$ dari keseluruhan penduduk Jakarta, tentu ini menjadi skala yang cukup kecil sehingga dapat dijadikan sebagai sebuah indikator sebagai etnis minoritas di Jakarta. Walaupun etnis Tionghoa sebagai minoritas, namun keterlibatannya dalam sektor perekonomian tidak dapat dipungkiri. Beberapa peran penting dalam sektor pemerintahan pun sudah mulai terisi oleh etnis Tionghoa.

Begitu juga dalam lingkungan pendidikan, etnis Tionghoa kini hadir disetiap kampus sebagai mahasiswa, khususnya beberapa kampus yang ada didaerah Jakarta. Bahkan untuk beberapa kampus di Jakarta, mahasiswa etnis Tionghoa justru menjadi mayoritas dari segi jumlah. Hal ini yang membuat ketertarikan peneliti untuk mengkaji lebih dalam lagi bagaimana para etnis
Tionghoa tersebut memaknai identitas minoritas mereka dalam interaksi sosial yang dilakukannya.

Penelitian ini menekankan pada dua hal yang akan dikaji yaitu berkaitan dengan pemaknaan yang dilakukan oleh mahasiswa etnis Tionghoa terkait dengan identitas minoritas dalam interaksi sosial yang mereka lakukan di lingkungan kampus khususnya, serta penekanan yang kedua yaitu berkaitan dengan pemaknaan pada proses interaksi sosial yang dilakukan oleh mahasiswa etnis Tionghoa dilingkungan pendidikan khususnya dilingkungan kampus atau universitas. Penelitian ini dilakukan di dua universitas yang berbeda di DKI Jakarta. Dengan mewawancarai 10 (sepuluh) informan yang memiliki latar belakang mahasiswa dari beberapa jurusan serta berasal dari Universitas Budi Luhur dan Universitas Bina Nusantara.

Terkait dengan makna identitas minoritas yang dikaji dalam penelitian ini, maka peneliti akan mengkaji pada tiga tingkatan identitas yang dimiliki oleh mahasiswa etnis Tionghoa di Universitas Budi Luhur dan Universitas Bina Nusantara. Tingkatan pertama adalah Personal Layer, yang terdiri dari rasa 
akan keberadaan diri anda dalam situasi sosial. Dalam situasi tertentu seperti ketika menghadiri gereja, bermain dengan teman, mendekati professor tentang nilai, atau bepergian bersama keluarga, anda melihat diri anda dalam kondisi-kondisi tertentu. Identitas tersebut terdiri dari berbagai perasaan serta ide tentang diri sendiri, siapa dan seperti apa diri anda sebenarnya.

Hal tersebut lebih banyak diungkapkan oleh informan dalam situasi kelas yang dialaminya, dimana beberapa informan di Universitas Bina Nusantara menyatakan bahwa tidak adanya diskriminasi ataupun perbedaan perlakuan dalam lingkungan kampus dan lingkungan kelas. Semua berjalan biasa saja selayaknya proses belajar mengajar yang harus dilalui. Seperti pernyataan yang disampaikan oleh $D i$ salah satu informan dari Universitas Bina Nusantara yang menyatakan bahwa proses belajar di kampus sangat santai, tidak adanya diskriminasi serta proses komunikasi yang berlangsung santai saja tanpa adanya memandang perbedaan etnis maupun golongan tertentu.

Namun diskriminasi justru pernah dialami dalam lingkungan rumahnya yang sempat ada kecurigaan yang dialami oleh tetangga tempat tinggalnya. Dan proses administrasi yang mendiskriditkan etnis Tionghoa pun pernah dialaminya ketika $D i$ mengurus pembuatan Kartu Tanda Penduduk (KTP) dilingkungan Jakarta. Namun disaat bersamaan $D i$ juga menyatakan bahwa, keberadaan keluarganya sebagai etnis Tionghoa sudah semakin diterima oleh lingkungan sosialnya seperti pernyataan berikut: "iya, kita juga suka ini kok, kan deket rumah saya itu banyak tukang bangunan dia juga kalo misalkan ada kendala dirumah mereka juga mau bantu, aman-aman aja sih rukun-rukun aja."

Selain lingkungan kampus dan lingkungan sosial, para informan juga menyatakan bahwa lebih banyak menghabiskan waktu bersosialisasi pada lingkungan tempat ibadah seperti Wihara dan Gereja. Dimana mereka merasa tidak adanya perbedaan apapun dan merasakan kenyamanan karena tidak adanya diskriminasi ketika mereka sering ke tempat ibadah. Seperti yang disampaikan oleh An yang menyatakan bahwa:"kalo diskriminasi sih tidak ada, soalnya saya sering ke wihara gitu. sering kumpul dengan orang diwihara jadi jarang gitu."

Namun ada perbedaan yang sangat signifikan yang dialami oleh mahasiswa Universitas Budi Luhur, sebagai etnis minoritas yang ada dilingkungan kampus. Tentu ini menjadi hal yang san- 
gat berbeda bagi mahasiswa etnis Tionghoa yang ada dilingkungan kampus Bina Nusantara yang mayoritas mahasiswanya adalah etnis Tionghoa. Sehingga dapat dilihat dengan jelas, bahwa lingkungan kampus sangat menentukan bagaimana para mahasiswa etnis Tionghoa ini harus berjuang menunjukkan eksistensinya dalam identitas etnis keturunan Tionghoa.

Seperti yang disampaikan oleh $M i$ yang masih mendapatkan ledekan dari temen-temannya yang berasal dari etnis yang berbeda. $M i$ menyatakan bahwa:

"Mungkin kalo rasis itu lebih banyak, kayak maaf-maaf ya bu, laki-lakinya langsung berkata ahh dasar lo Cina gitu. itu sih menurut saya kasar tapi menurut saya ahh biasalah jaman sekarang kan. Mungkin menurut mereka perkataan yang kayak gitu udah biasa. Jadi saya mikirnya ngapain juga gua Baper (Bawa Perasaan). Toh juga gua punya banyak temen kok gak Cuma lo, itu doang yang saya pikirin. Terus saya sih PD-PD (Percaya Diri) aja."

Beberapa informan dari

Universitas Budi Luhur juga menyatakan bahwa, perlu adanya pemahaman untuk menjaga sikap ketika akan berteman dengan teman-teman yang berbeda etnis. Hal tersebut dilakukan karena mereka sangat sadar dengan kondisi mereka yang minoritas. seperti yang disampaiakan oleh $A d$, mahasiswa Universitas Budi Luhur yang kesehariannya selalu membawa bekal makanan dari rumahnya. Dimana terkadang harus berhati-hati dengan bekal yang dibawa ke kampus dan selalu mendapat pertanyaan dari teman-temannya yang berbeda etnis. Seperti pernyataan yang disampaikan oleh Ad: "Paling kalo jaga-jaga paling kalo lagi makan gitukan." Setelah diam beberapa saat lalu $A d$ melanjutkan kalimatnya dengan intonasi yang lebih lirih yaitu : "kan ada yang bawa bekal, kan takutnya. ini makan apa gitu. kan biasanya ada yang nanya kan wajar. udah itu paling apalagi ya.."

Tingkatan kedua adalah Enactment Layer atau pengetahuan orang lain tetang diri anda berdasarkan pada apa yang anda lakukan, apa yang anda miliki, dan bagaimana anda bertindak. Penampilan anda adalah simbol-simbol aspek anda serta orang lain akan mendefinisikan dan memahami anda melalui penampilan tersebut. Dalam tingkatan ini, ada kecendrungan mahasiswa etnis Tionghoa yang berada di Universitas Bina Nusantara membangun eksklusifitas sosialisasi, dimana ada kecendrungan untuk membagun tindakan sosialisasi pada sesama etnis Tionghoa. Sehingga sangat terlihat perbedaan lingkungan kampus antara mahasiswa etnis Tionghoa dan mahasiswa pribumi. Hal tersebut sempat peneliti tanyakan 
pada sekelompok mahasiswa pribumi yang ada dilingkungan kampus, ketika peneliti berhendak mewawancarai mahasiswa etnis Tionghoa, dengan nada hampir serempak mereka menyatakan: "Ohhh disana bu, mereka biasanya nokrong ditengah bu”. Seperti pada gambar berikut ini:

\section{Gambar 1}

Suasana Sosialisasi Mahasiswa Etnis Tionghoa di Universitas Bina Nusantara

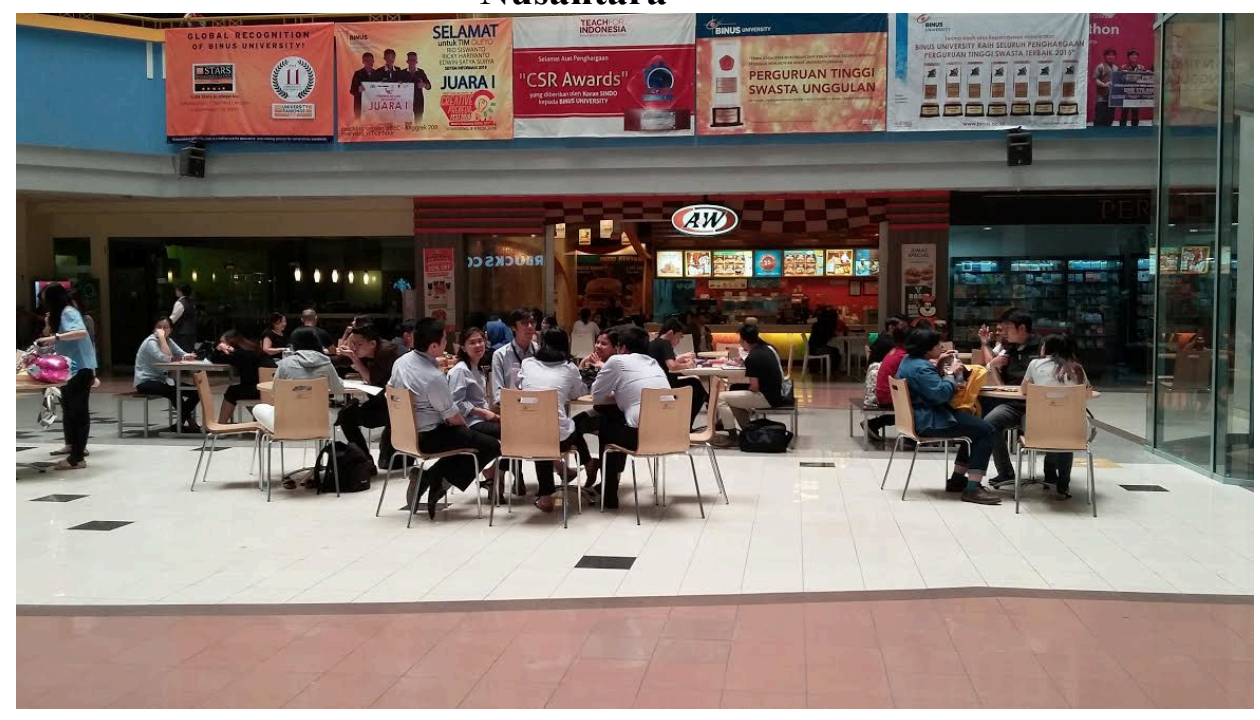

Tingkatan yang ketiga dalam identitas anda adalah Relational atau siapa diri anda dalam kaitannya dengan individu lain. Identitas dibentuk dalam interaksi anda dengan mereka. Anda dapat melihat dengan sangat jelas identitas hubungan ketika anda merujuk diri anda secara spesifik sebagai mitra hubungan, seperti ayah, suami istri, rekan kerja. Perhatikan bahwa identitas anda menjadi terikat kepada peran tertentu yang berhadap-hadapan dengan peran lain, seperti "bos', "sahabat karib", "koki", atau "konsuler". Oleh karena itu, pada tingkat hubungan, identitas sangat tidak individualis, tetapi terikat pada hubungan itu sendiri. Tanyalah diri anda seperti apa hubungan anda dengan ibu anda, kekasih atau teman sekamar dan mulailah memvisualisasikan identitas hubungan ini. Littlejohn\&Foss $(2009 ; 131)$

Seperti yang dinyatakan oleh beberapa informan yang lahir dan besar di Jakarta, yang meyatakan bahwa, kecendrungan hubungan keterikatan antara keluarga mereka cenderung santai. Dan seluruh informan menyatakan tidak menggunakan bahasa daerah dalam komunikasi sehari-harinya, cukup menggunakan bahasa Indonesia saja. Penggunakaan bahasa daerah hanya 
digunakan oleh orang tua mereka pada nenek mereka atau orang yang dianggap dituakan dalam lingkungan keluarga mereka. Kekeraban keluarga biasanya dirasakan pada perayaan-perayaan keluarga saja seperti perayaan tahun baru Imlek atau acara pernikahan. Karena pada momen-momen tersebutlah seluruh anggota keluarga berkumpul dalam pesta yang sebagian besar masih menggunakan adat Tionghoa. Seperti yang disampaikan oleh $F e$ yang menjelaskan tradisi keluarga ketika ada perayaan pernikahan yaitu:

"Nahhh, jadi ada namanya Samjit. Jadi kalo misalnya sebelum nikah ni, kan pertama lamaran dulu setelah itu terus Samjit. Samjit itu kaya penyerahan gitu, itu dilakuin dua atau tiga hari sebelumnya. Kalo disini namanya tunangan deh. ya kalo lamar gitu cowonya datang kerumah cewe. Nah kalo Samjit itu tukeran jadi si cewe ngasih barang ke cowo. cowonya ngasih barang ke cewe ngasih sembako juga.". setelah berhenti sejenak, $\mathrm{Fe}$ kembali menjelaskan: "terus ada lagi Tepai. Kalo saya kan Katolik ya, jadi pertama pemberkatan dulu, terus ke catatan sipil nah setelah itu baru ada Tepai. Tepai itu kaya orang tua ngasih wejangan ke anak yang mau nikah. mau kasih wejangan boleh mau kasih nasehat boleh. terus nanti anaknya kasih teh. mau ngasih angpau boleh, bebas sih mau ngasih hadiah atau ngasi wejangan aja juga boleh. mau ngasih benda turun temurun gitu juga boleh. Mungkin kalo Sambit itu masih pake baju Tong Sam gitu."

Kedekatan dalam lingkungan keluarga juga dirasakan oleh beberapa informan melalui nasehat-nasehat yang cenderung disampaikan oleh orang tua mereka. Seperti berhati-hati dalam memilih teman dan selalu menjaga sikap disaat memilih teman. Selalu menghormati orang lain yang ada disekeliling. Intensitas nasihat pun berbeda, dari hasil wawancara yang telah dilakukan oleh peneliti bahwa, beberapa informan yang berasal dari Universita Bina Nusantara yang lahir dan besar di Jakarta cenderung lebih santai dan tidak menjelaskan secara detail bentuk nasihat orang tua mereka, dengan alasan orang tua mereka sibuk bekerja. Namun berbeda dengan informan yang tidak lahir dan besar di Jakarta yang harus kost karena orang tua mereka tinggal diluar kota. Pesan-pesan moral cenderung lebih sering didengarkan dan diberikan oleh orang tua mereka.

Akhirnya, tingkatan keempat dalam identitas adalah tingkatan Communal, yang diikat pada kelompok atau budaya yang lebih besar. Tingkat identitas ini sangat kuat dalam banyak budaya Asia, misalnya, ketika identitas seseorang dibentuk terutama oleh komunitas yang lebih besar daripada oleh 
perbedaaan individu diantara manusia dalam komunikasi. Kapan pun anda memperhatikan apa yang dipikirkan dan dilaksanakan oleh komunitas anda, maka anda menyesuaikan diri pada tingkatan identitas anda tersebut. Littlejohn\&Foss $(2009 ; 132)$
Hal tersebut dapat dilihat dari budaya mayoritas yang dibentuk, dimana mahasiswa etnis Tionghoa Universitas Bina Nusantara cenderung untuk berteman dan berdiskusi dengan sesama mahasiswa etnis Tionghoa saja. Seperti pada gambar berikut:

\section{Gambar 2}

Interaksi sosial Mahasiswa Etnis Tionghoa di Universitas Bina Nusantara.

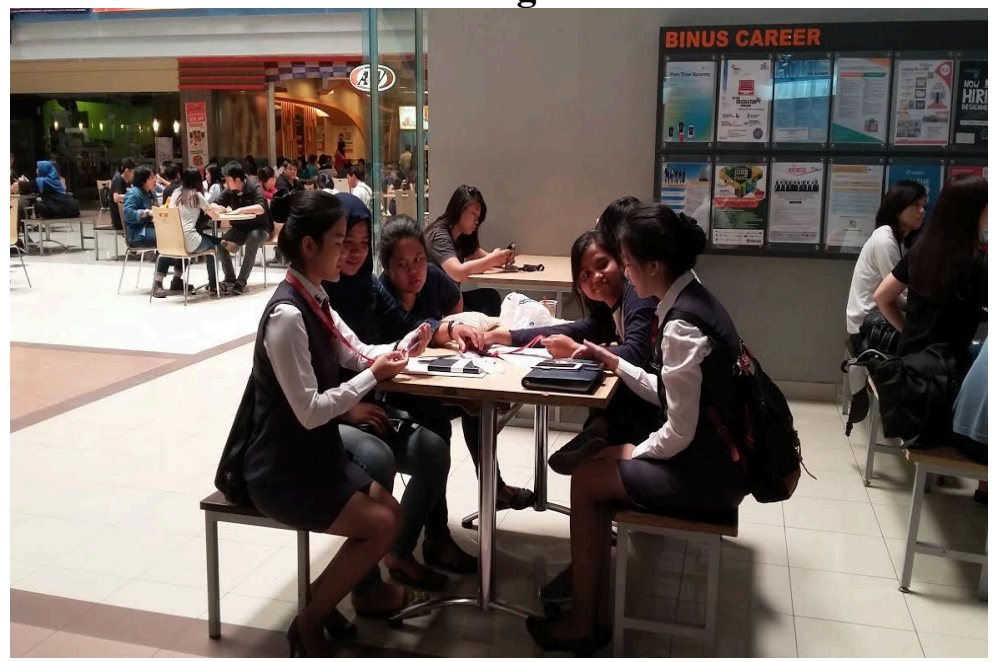

Adanya perbedaan yang

signifikan pada lingkungan kampus

Universitas Budi Luhur di mana

mahasiswa etnis Tionghoa cenderung berbaur dengan mahasiswa etnis lainnya dikarena mahasiswa etnis Tionghoa di lingkungan ini sangat minoritas. Seperti pada gambar berikut ini:

Gambar 3

Interaksi mahasiswa Etnis Tionghoa di Universitas Budi Luhur

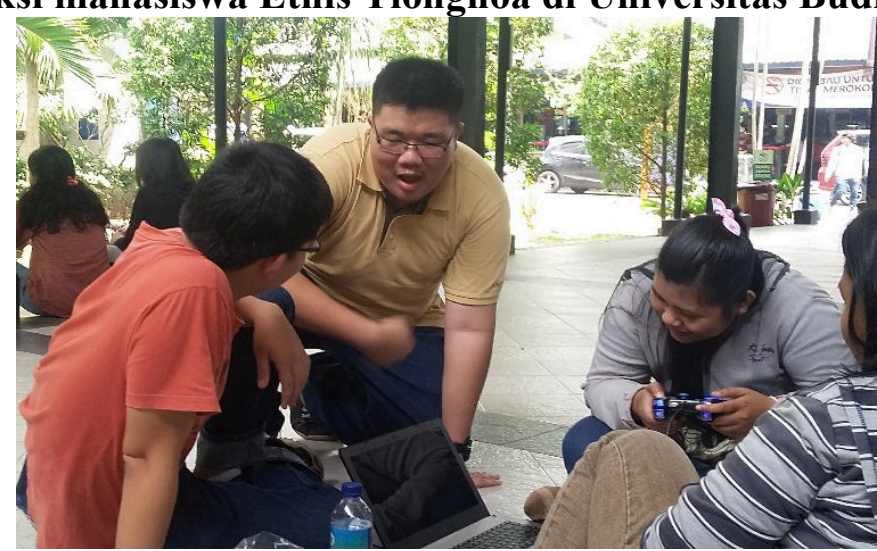


Etnisitas sebagai Identitas Minoritas

a. Sangat Merasa Sebagai Minoritas

Berdasarkan hasil penelitian dilapangan ditemukan bahwa seluruh informan yang diwawancarai sangat merasa bahwa mereka adalah minoritas. Sehingga hal tersebut sangat mempengaruhi interaksi sosial yang akan dilakukannya. Kesadaran penuh terhadap identitas minoritas yang dimiliki berdampak signifikan terhadap pemilihan teman dalam proses interaksinya. Mereka cenderung berhati-hati dalam mememilih teman serta bertutur kata. Mereka pun sangat menjadi sikap mereka ketika berinteraksi dikarenakan kesadaran yang mereka miliki sebagai etnis minoritas.

\section{b. Kuatnya Tradisi Tionghoa da- lam Keluarga}

Hal yang menarik terkait dengan pemahaman identitas minoritas yang dimiliki oleh seluruh informan adalah berawal dari pemahaman yang dibangun dari pola didik keluarga. Dimana keluarga memiliki peranan penting untuk membangun kesadaran terhadap minoritas etnis Tionghoa. Seluruh informan menyatakan dengan sadar bahwa mereka masih menjalankan tradisi-tradisi Tionghoa dalam kesehariannya di rumah. Bukan hanya perayaan Imlek yang dirayakan oleh seluruh etnis Tionghoa di dunia, namun juga perayaan ulang tahun yang dirayakan bukan hanya berdasarkan penanggalan nasional, namun juga berdasarkan penanggalan China. Bukan hanya itu saja, tradisi-tradisi lainnya seperti tradisi makan, mengucapkan salam, etika sopan santun kepada yang tua, etos kerja, dll masih ditekankan sangat kuat di rumah mereka.

\section{c. Adanya penguatan terhadap pendamping hidup sesama et- nis Tionghoa}

Keluarga juga memiliki peranan penting untuk membangun masa depan. Demikian juga dengan pemaparan yang dilakukan oleh seluruh informan dalam penelitian ini yang menyatakan bahwa, sedari kecil penguatan terhadap identitas Tionghoa juga dilakukan dalam petuahpetuah yang diberikan oleh orang tua berkaitan dengan pendamping hidup dimasa depan. Dimana mereka diberikan pemahaman yang sama yaitu pendamping bhidup harus berasal dari etnis Tionghoa sehingga pelestarian terhadap budaya leluhur masih terjaga.

\section{d. Pola didik yang bangga men- jadi etnis Tionghoa}

Pola didik keluarga juga memiliki peranan penting dalam proses pemahaman terhadap etnisitas yang dimiliki oleh para etnis Tionghoa ini. Dimana keluarga memberikan pemahaman yang 
sangat kental untuk bangga dengan etnis yang dimilikinya walupun mereka minoritas. Seluruh informan menyatakan bahwa, mereka bangga sebagai etnis Tionghoa yang memiliki etos kerja yang sangat ulet serta kegigihan dalam menghadapi hidup. Orang tua pun selalu menyatakan kepada anak-anaknya untuk selalu bangga sebagai etnis Tionghoa.

\section{e. Masih mempertimbangkan} tentang Etnisitas (Mereka menyebutnya Rasisme)

Kesadaran penuh yang dimiliki oleh seluruh informan dalam penelitian ini yang menyatakan bahwa "saya sangat bangga sebagai etnis Tionghoa walaupun masih banyak yang belum bisa menerima kami sebagai etnis Tionghoa". Walaupun Rasisme (istilah yang mereka gunakan) masih saja ada, namun itu diabaikan, yang terpenting adalah kebanggaan menjadi etnis Tionghoa dan senantiasa berperilaku baik karena kesadaran mereka bahwa mereka adalah minoritas.

\section{Interaksi Sosial yang Dil- akukan oleh Mahasiswa Etnis Tionghoa di Universitas Budi Luhur dan Universitas Bina Nusantara.}

\section{a. Etnisitas Sebagai Landasan da- lam Berinteraksi}

Pada proses inteeraksi sosial yang dilakukan oleh mahasiswa etnis Tionghoa yang ada di Universitas Budi Luhur dan Universitas Bina Nusantara, dimana entisitas masih menjadi landasan kuat untuk mereka membangun interaksi yang dilakukan dilingkungan kampus atau institusi pendidikan. Dimana kecendrungan dari mereka untuk memilih teman pergaulan sesama etnis Tionghoa dulu karena berkaitan dengan kesamaan-kesamaan yang dimiliki dan dipahami. Setelah itu mereka baru membuka pergaulan ke mahasiswa pribumi yang tidak mempermasalahkan perbedaan etnis yang mereka miliki.

Proses interaksi yang dilakukan tentu sangat berbeda antara mahasiswa etnis Tionghoa yang ada dalam lingkungan mayoritas dan lingkungan minoritas. Dalam lingkungan mayoritas seperti di Universitas Bina Nusantara, mahasiswa etnis Tionghoa memiliki lebih banyak pilihan dengan tingkat kepercayaan diri yang mereka miliki. Mereka lebih bisa menentukan apakah akan berteman dengan sesama etnis atau diluar etnis. Dari hasil wawancara yang dilakukan oleh peneliti dimana beberapa informan mahasiswa dari Universitas Bina Nusantara memiliki teman diluar etnis Tionghoa, umumnya berasal dari etnis Jawa dan Sumatera, tentunya dengan jumlah yang sangat sedikit. Seperti yang disampaikan oleh $\mathrm{Fe}$ yang menyatakan bahwa: "ada, tapi nggak banyak, 
yaaa..dari Jawa ada. Kayaknya sih rata antara Jawa dan Sumatera." Serta dikuatkan dengan pernyataan yang disampaikan oleh $T i$ yang menyatakan bahwa: "ada beberapa aja...mungkin ada Jawa ada Kalimantan. Awalnya sih sulit adaptasinya tapi kalua sudah lama sih mereka santai aja." Seperti pada gambar berikut ini, dimana mahasiswa etnis Tionghoa sebagai mayoritas di Universitas Bina Nusantara cenderung memilih berteman pada etnis yang sama.

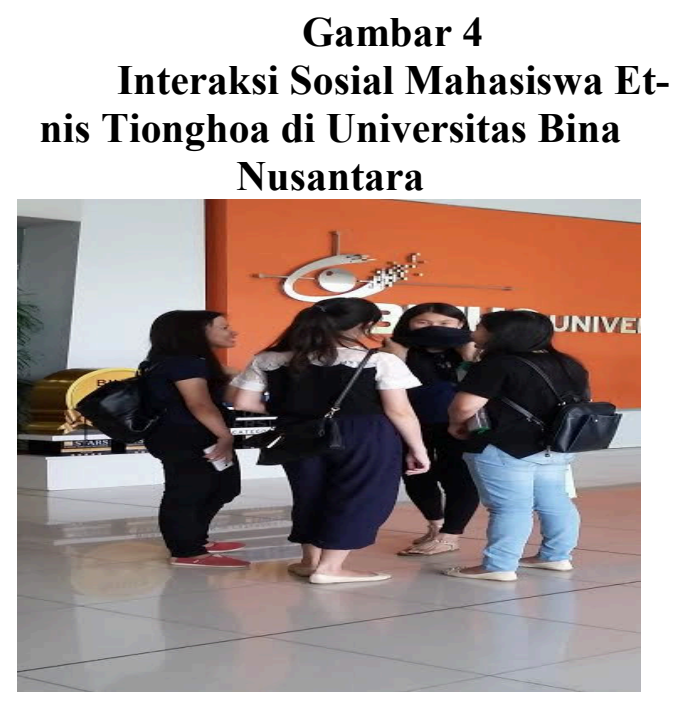

Namun, walaupun cenderung berteman dengan sesama etnis, namun tidak menutup kemungkinan juga bahwa para mahasiswa etnis Tionghoa tersebut juga berteman dengan teman-teman kuliah yang berasal dari etnis yang berbeda walaupun tidak banyak. Dalam proses interaksi sosial yang dilakukan antara mahasiswa pribumi dan mahasiswa etnis Tionghoa adalah kecendrungan yang mempengaruhi dalam interaksi mereka.
Dimana mahasiswa pribumi berinteraksi dengan mereka untuk mengetahui bagaimana detail budaya Tionghoa sehingga proses pembelajaran yang dilakukan oleh mahasiswa pribumi terhadap mahasiswa etnis Tionghoa, proses pembelajaran juga dilakukan baik dari sisi perayaan tahun baru Cina yang dilakukan oleh mahasiswa etnis Tionghoa setiap tahunnya, preferensi makanan yang dimiliki oleh mahasiswa etnis Tionghoa dan mahasiswa pribumi, hingga profesi yang dihendaki di masa mendatang yang kecendrungan lebih banyak berkutat pada profesi dibidang perniagaan dan perekonomian.

\section{b. Agama dalam Proses Interaksi Sosial Mahasiswa Etnis Tiong- hoa}

Hal menarik yang ditemukan dalam proses wawancara kepada informan yeng berlatar belakang etnis Tionghoa adalah agama yang dianut mereka menentukan kepercayaan diri yang dimiliki. Hal tersebut dapat dilihat dari intonasi suara mereka yang ragu-ragu dan lirih namun ada yang menyampaikan dengan intonasi yang lantang dan lugas. Bukan hanya itu saja, kepercayaan diri tersebut juga dapat dilihat dari keberanian mereka membangun interaksi sosial yang dilakukankannya dalam lingkungan kampus. Dimana berdasarkan hasil penelitian yang dilakukan, bahwa mahasiswa etnis 
Tionghoa yang memiliki latar belakang keyakinan beragama Kristen lebih percaya diri dibandingkan mahasiswa etnis Tionghoa yang memiliki latar belakang agama Budha.

Bukan hanya itu saja, yang menjadi kesamaan dari semua informan adalah mahasiswa etnis Tionghoa yang beragama Kristen cenderung tidak terlalu memahami budaya etnis Tionghoa dan lebih mengikuti cara-cara Barat dalam perayaan keluarga. Sangat berbeda dengan mahasiswa etnis Tionghoa yang beragama Budha yang masih kuat dengan tradisi-tradisi Tionghoa yang berlaku dikeluarga mereka.

\section{c. Bahasa dalam Proses Interaksi}

\section{Sosial Mahasiswa Etnis Tiong-}

\section{hoa}

Bahasa yang digunakan dalam interaksi sosial mahasiswa etnis Tionghoa ini sangat beragam, ada yang menggunakan bahasa Tio_Cew, Hokian, Mandarin, Khe, dll. Mereka menyebutnya dengan "Bahasa Kami" sebagai penguatan terhadap rasa kepemilikian dari bahasa tersebut. Seluruh informan menggunakan bahasa Etnik tersebut dalam interaksi sosial yang dilakukan diluar lingkungan kampus ataupun jika sedang berinteraksi dengan sesama mahasiswa dari etnis Tionghoa yang ada di lingkungan kampus yang sama.

\section{d. Stereotipe Budaya dalam Proses Interaksi Sosial}

Stereotipe terhadap budaya tertentu khususnya untuk mahasiswa Etnis Tionghoa masih saja terjadi walau masih dalam konteks bercanda anak mahasiswa. Namun yang menarik adalah para mahasiswa etnis Tionghoa tersebut tidak emosi atau bahkan cenderung mengabaikan ejekan tersebut. Menurut mereka itu hanyalah candaaan yang tidak perlu dibuat tersinggung. Justru statement tersebut semakin mengauatkan identitas etnisitas yang mereka miliki dan selalu melekat dalam proses interaksi sosial yang mereka lakukan dilingkungan kampus.

Bahkan beberapa informan dari lingkungan mayoritas cenderung mengabaikan dan mahasiswa etnis Tionghoa dari lingkungan minoritas cenderung mencari solusi dengan merangkul mereka untuk berteman. Seperti yang disampaikan oleh $M i$ berikut ini:

"Saya tu suku apa dan agama apa? itu paling pertama. Terus kalo misalkan kita ngobrol punya banyak temen-temen yang muslim gitu, ya puji Tuhan sih mereka enggak terlalu rasis atau gimana paling yang sering kita obrolin tu, apa kalo di cina itu gimana sih ibadahnya atau ritual-ritualnya gitu, jadi kita kayak saling bertukar informasi gitu. soal suku dan agama masing-masing gitu." 


\section{Institusi Pendidikan juga menentukan Keaktifan dan Eksistensi Mahasiswa Etnis Tionghoa}

Institusi pendidikan juga mampu mempengaruhi kepercayaan diri yang mereka miliki sebagai etnis Tionghoa. Yang tentu saja akan mempengaruhi keaktifan dan eksistensi mereka sebagai mahasiswa etnis Tionghoa yang harus mampu membangun interaksi didalam lingkungan kampus. Hal ini tentu sangat berbeda, kepercayaan diri yang dimiliki oleh mahasiswa etnis Tionghoa yang ada dilingkungan kampus yang mayoritas mahasiswanya dari etnis Tionghoa dengan yang tidak. Untuk mahasiswa yang menempuh pendidikan di lingkungan kampus yang didominasi oleh masyarakat pribumi bukan etnis Tionghoa, maka kecenderungannya mahasiswa etnis Tionghoa ini lebih berhati-hati dalam melakukan interaksi sosialnya serta memiliki keaktifan dan eksistensi yang kurang.

\section{Institusi Pendidikan Menen- tukan Tingkat Kepercayaan Diri}

Institusi pendidikan juga mampu mempengaruhi kepercayaan diri yang mereka miliki sebagai etnis Tionghoa. Yang tentu saja akan mempengaruhi proses interaksi sosial yang akan dilakukan oleh mereka sebagai mahasiswa etnis Tionghoa yang harus mampu dibangun didalam lingkungan kampus. Hal ini tentu sangat berbeda, kepercayaan diri yang dimiliki oleh mahasiswa etnis Tionghoa yang ada dilingkungan kampus yang mayoritas mahasiswanya dari etnis Tionghoa dengan yang tidak. Untuk mahasiswa yang menempuh pendidikan di lingkungan kampus yang didominasi oleh masyarakat pribumi bukan etnis Tionghoa, maka kecenderungannya mahasiswa etnis Tionghoa ini lebih berhati-hati dalam melakukan interaksi sosialnya serta memiliki kepercayaan diri yang kurang.

\section{Pemaknaan Identitas Minoritas pada Lingkungan Mayoritas Tionghoa.}

\section{Institusi Pendidikan menen- tukan Kelas Sosial Etnis Tiong- hoa}

Institusi pendidikan juga mampu mempengaruhi kelas sosial yang mereka miliki sebagai etnis Tionghoa. Yang tentu saja akan mempengaruhi proses interaksi sosial mereka sebagai mahasiswa etnis Tionghoa yang harus mampu dibangun didalam lingkungan kampus. Klasifikasi kelas social yang mereka miliki ditentukan berdasarkan pernyataan yang disampaikan oleh para informan, seperti mahasiswa etnis Tionghoa yang berkuliah di Universitas Budi Luhur itu masuk dalam kategori kelas bawah, mahasiswa etnis Tionghoa yang berkuliah di Universitas Atma Jaya itu masuk dalam 
kategori kelas menengah, sementara mahasiswa etnis Tionghoa yang berkuliah di Universitas Bina Nusantara yang mayoritas etnis Tionghoa itu masuk dalam kategori kelas atas. Kategori ini didasarkan pada kelas sosial ekonomi yang dimiliki oleh mahasiswa etnis Tionghoa.

\section{Institusi pendidikan menen- tukan Tingkat Kepercayaan Diri}

Institusi pendidikan juga mampu mempengaruhi kepercayaan diri yang mereka miliki sebagai etnis Tionghoa. Yang tentu saja akan mempengaruhi proses interaksi sosial mereka sebagai mahasiswa etnis Tionghoa yang harus mampu dibangun didalam lingkungan kampus. Hal ini tentu sangat berbeda, kepercayaan diri yang dimiliki oleh mahasiswa etnis Tionghoa yang ada di lingkungan kampus yang mayoritas mahasiswanya dari etnis Tionghoa dengan yang tidak. Untuk mahasiswa yang menempuh pendidikan di lingkungan kampus yang didominasi oleh etnis Tionghoa, maka kecenderungannya mahasiswa etnis Tionghoa ini akan memiliki kepercayaan diri yang sangat tinggi karena mahasiswa etnis Tionghoa ini merasa sebagai mayoritas dalam lingkungan kampus tersebut walaupun setelah keluar kampus mereka kembali pada identitas awal yaitu sebagai etnis minoritas.

\section{Bagan 1}

Makna Minoritas Dalam Interaksi Sosial Mahasiswa Etnis Tionghoa

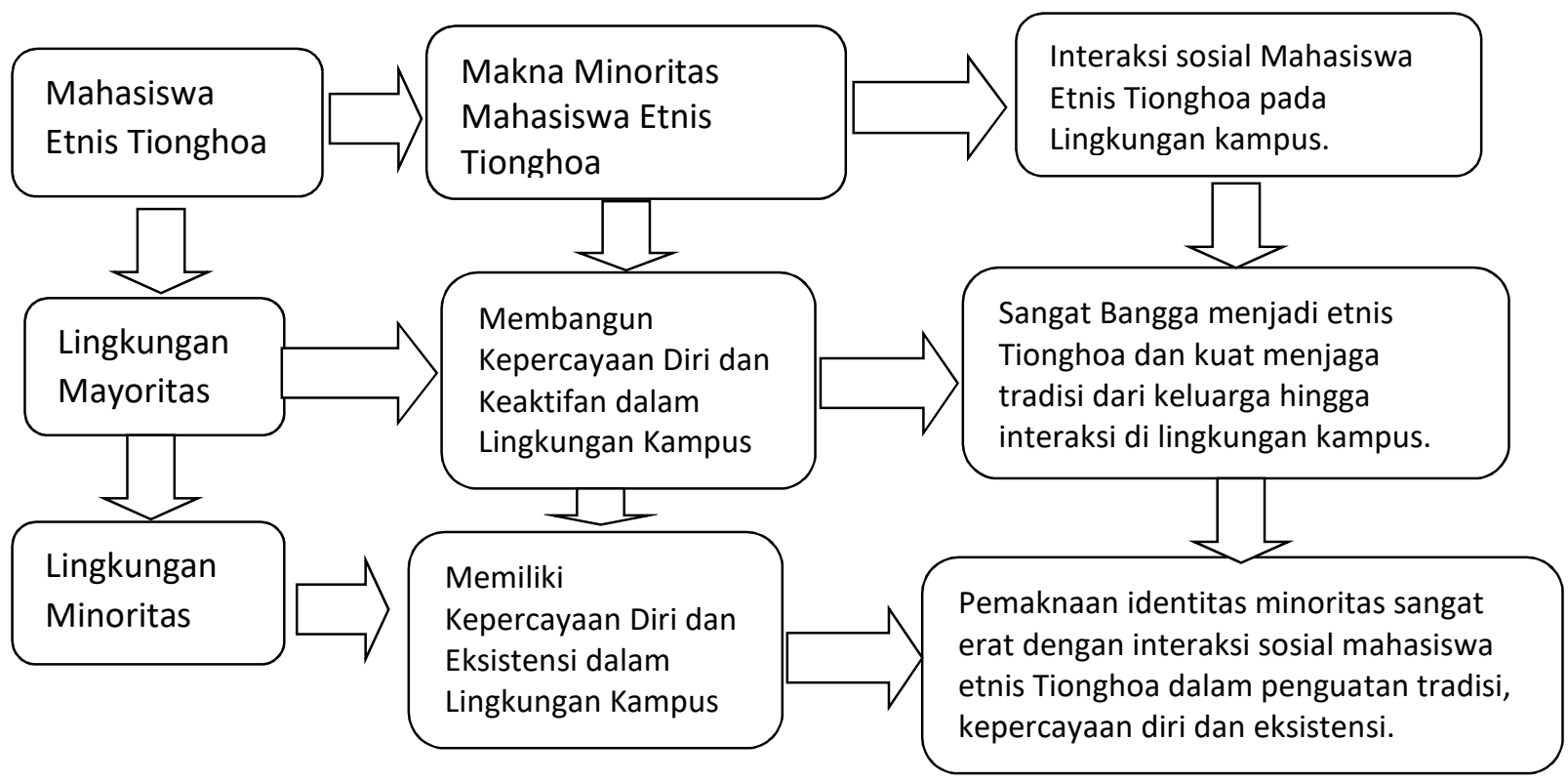

Sumber: Diolah dari hasil penelitian, 2017.

\section{SIMPULAN}


Identitas sebagai minoritas memang menjadi hal yang sangat menarik untuk dikaji, walaupun isu ini menjadi sangat sensitive jika ditelaah secara detail dalam penelitian yang menggunakan pendekatan kualitatif. Terkait dengan konstruksi makna minoritas etnis Tionghoa, maka sebagai kesimpulan dalam penelitian ini akan menekankan pada dua hal yaitu:

1. Pemaknaan identitas minoritas etnis Tionghoa memiliki keterkaitan yang sangat erat dengan proses interaksi sosial yang dilakukan. Dimana kesadaran yang mereka tampilkan dalam kebanggaan menjadi seorang keturunan Tionghoa dengan terus menjaga tradisi-tradisi Tionghoa yang ditanam sangat kental dimulai dari keluarga dan mereka yakni sebagai sebuah pondasi dalam menentukan sikap dan perilaku pada saat mereka membangun proses interaksi baik sesama etnis Tionghoa maupun dengan masyarakat pribumi dilingkungan kampus atau universitas.

2. Terkait dengan interaksi sosial yang dilakukan oleh mahasiswa etnis Tionghoa di lingkungan pendidikan pun menjadi sangat variatif dimana agama, bahasa hingga stereotype budaya yang mereka miliki menjadi varianvarian atau warna tersendiri dalam proses interaksi sosialnya. Yang menarik juga adalah kondisi lingkungan pendidikan yang mengambil peran cukup besar untuk menentukan kepercayaan diri yang mereka miliki, apakah mereka ada dalam lingkungan pendidikan mayoritas ataupun dalam lingkungan pendidikan minoritas etnis Tionghoa. Karena kesemua hal tersebut ternyata memiliki kaitan yang sangat signifikan terhadap kepercayaan diri serta eksistensi mereka dalam proses interaksi sosial yang dilakukannya.

\section{UCAPAN TERIMA KASIH}

Ucapan terimakasih peneliti haturkan kepada Tuhan Yang Maha Esa atas segala berkat dan karunianya, kedua orang tua peneliti yang telah memberikan segala doa, Suami serta keluarga besar peneliti yang senantiasa mendukung proses penelitian ini. Terimakasih yang mendalam peneliti ucapkan juga kepada Universitas Budi Luhur dan Universitas Bina Nusantara, Dekan Fakultas Ilmu Komunikasi Universitas Budi Luhur, serta seluruh dosen dan mahasiswa yang 
selama ini telah membantu proses

penyelesaian penelitian ini.

\section{DAFTAR PUSTAKA}

\section{Buku-Buku:}

Cashomore, E.1996 Dictionary of Race and Ethnic Relations. Edisi ke-2. London: Routledge.

Creswell, Jhon W, 1998, QUALITATIVE INQUIRY AND RESEARCH DESIGN Choosing Among Five Traditions, SAGE Publication.

Creswell, Jhon W, 2013, Edisi Ketiga, RESEARCH DESIGN; Pendekatan Kualitatif, Kuantitatif, dan Mixed, Pustaka Pelajar, Yogyakarta.

George Ritzer\&Barry Smart, 2011, Handbook Teori Sosial, Penerbit Nusa Media, Bandung

Goffman, Erving, 1967, Interaction Ritual, Essays on Face - to - Face Behavior, United States of America.

Griffin, EM, 2006, A First Look At COMMUNICATION THEORY, Sixth Edition, Mc Graw - Hill Education.

Jary, D. dan J. Jary (peny). 1999. Unwin Human Dictionary of Sociology. Edisi ke-2. Leicester: Bookmart Ltd.

Kymlicka, W. 1995.Multicultural Citizenship. Cambridge: Cambridge University Press.

Lindlof, Thomas R, 1995, QUALITATIVE

COMMUNICATION RESEARCH METHODS, Current Communication : An Advanced Text Series Volume 3, SAGE Publications.

Littlejohn, Stephen W, 1996, TEORI KOMUNIKASI Nine Edition THEORIES OF HUMAN COMMUNICATION, Salemba Humanika, 2009.

Miles, B. Matthew, A. Michael Hubermas, 1992, Analisis Data
Kualitatif, Buku Sumber Tentang Metode-Metode Baru, Jakarta : UI Press.

Moleong, Lexy, J, Dr, M.A., 2006, METODOLOGI PENELITIAN KUALITATIF Edisi Revisi, PT. Remaja Rosdakarya, Bandung.

Mulyana, Deddy, M. A, 2005, Ilmu Komunikasi, Suatu Pengantar, PT. Remaja Rosdakarya, Bandung.

Mulyana, Deddy, M. A, 2004, Metodologi Penelitian Kualitatif, Paradigma Baru Ilmu Komunikasi Dan Ilmu Sosial Lainnya, PT. Remaja Rosdakarya, Bandung.

Mulyana, Deddy, M. A, Solatun, Dr, Msi, 2007, Metodologi Penelitian Kualitatif, Contoh - Contoh Penelitian Kualitatif Dengan Pendekatan Praktis, PT. Remaja Rosdakarya, Bandung.

Norman K Denzin\&Yvonna S. Lincoln, 2009, Handbook of QUALITATIVE RESEARCH, Pustaka Pelajar, Yogyakarta.

Rohim, Syaiful, 2009, TEORI KOMUNIKASI, Perspektif, Ragam, \&Aplikasi, PT. Rineka Cipta, Jakarta.

Salim, Agus, 2001. TEORI DAN PARADIGMA PENELITIAN SOSIAL, Tiara Wacana Yogya, Yogyakarta

Walsh, George and Lehnert, Frederick, 1972, The Phenomenology of the Social World, Heinemann Educational Books, London

\section{Sumber Online:}

http://www.tionghoa.info/suku-tionghoa-di-indonesia/

Sumber:http://demografi.bps.go.id/phpfiletree/bahan/kumpulan tugas mobilitas pak chotib/Kelompok 1/Referensi/BPS_kewarganegaraan_sukubangsa _agama_bahasa_2010.pdf 